\title{
First report of Corynespora cassiicola on Pueraria phaseoloides (tropical kudzu)
}

\author{
W. S. Lisboa ${ }^{1}$ - D. M. Macedo ${ }^{1} \cdot$ M. Silva ${ }^{1} \cdot$ R. W. Barreto ${ }^{1}$
}

Received: 13 October 2015 / Accepted: 26 April 2016/Published online: 1 May 2016

(C) Australasian Plant Pathology Society Inc. 2016

\begin{abstract}
Pueraria phaseoloides (tropical kudzu) is a plant native from Southeast Asia, which is widely used in pastures. In 2014 individual plants with leaf spots were found in Viçosa (State of Minas Gerais, Brazil). Morphology of the causal fungus was typical of Corynespora cassiicola. ITS sequence analysis indicated a high homology with other sequences available for this species in GenBank. This is the first record of this host-pathogen relationship worldwide.
\end{abstract}

Keywords Cover crop · Fabaceae · Hyphomycete · Legume · Pasture

Pueraria phaseoloides (Fabaceae), also known as tropical kudzu (TK) is a perennial legume native to Malaysia and Indonesia. It is commonly used in grass and legume pastures as cover crop or green manure (Deminicis 2009).

Only three species of plant pathogenic fungi are known to attack TK in Brazil (Mendes and Urben 2015).

Tropical kudzu plants have been observed in Viçosa (state of Minas Gerais, Brazil) with leaf spots that started as punctiform brown necrotic spots, which became circular (1.0-6.5 mm diam) and coalesced, leading to leaf chlorosis and premature senescence (Fig. 1).

R. W. Barreto

rbarreto@ufv.br

1 Departamento de Fitopatologia, Universidade Federal de Viçosa, Viçosa, Minas Gerais 36570-900, Brazil
Samples were taken, dried in a plant press and brought to the laboratory for further analysis. A fungus was regularly found in association with the diseased leaves and the samples were dried and deposited as VIC 42927 in the Herbário da Universidade Federal de Viçosa, state of Minas Gerais, Brazil. The fungus was isolated in pure culture and deposited as COAD 1834 at the culture collection Coleção Otávio de Almeida Drumond. Fungal structures were mounted in lactic acid and slides were observed under a light microscope (Olympus BX 51).

The fungus had the following morphology: internal mycelium intra and intercelular, 3-4 $\mu \mathrm{m}$ diam, branched, septate, hyaline to subhyaline; conidiophores mostly solitary, straight, cylindrical, 300-1000 ×4-7 $\mu \mathrm{m}, 4-9$ septate, dark brown; conidiogenous cells terminal integrated, proliferating percurrently, 80-170 $\times 4-7 \mu \mathrm{m}$, cylindrical, pale brown; conidia either isolate or forming acropetal chains, fusiform to subcylindrical, $70-360 \times 6-13 \mu \mathrm{m}$, base truncate, $3-21$ septate, hilum thickened and darkened, brown to pale brown, smooth (Fig. 2). This morphology is consistent with that described for Corynespora cassiicola (Ellis and Holliday 1971).

DNA was extracted from COAD 1834 with a Wizard $\AA$ Genomic DNA purification kit (Promega, USA) and the ITS region was amplified with primers ITS4 and ITS5 (White et al. 1990). Sequencing was performed by Macrogen Korea (www. macrogen.com) and, after processing, it was deposited in GenBank (Accession No. KT381464). This sequence had a high similarity to approximately fifty sequences of C. cassiicola (458/458 identities to KP666184). Unfortunately, there are no ex-type sequences of this important fungal species, available for comparison.

Inoculation of two healthy TK plants was performed with both conidial suspension $\left(8 \times 10^{4}\right.$ conidia/mL) and culture 


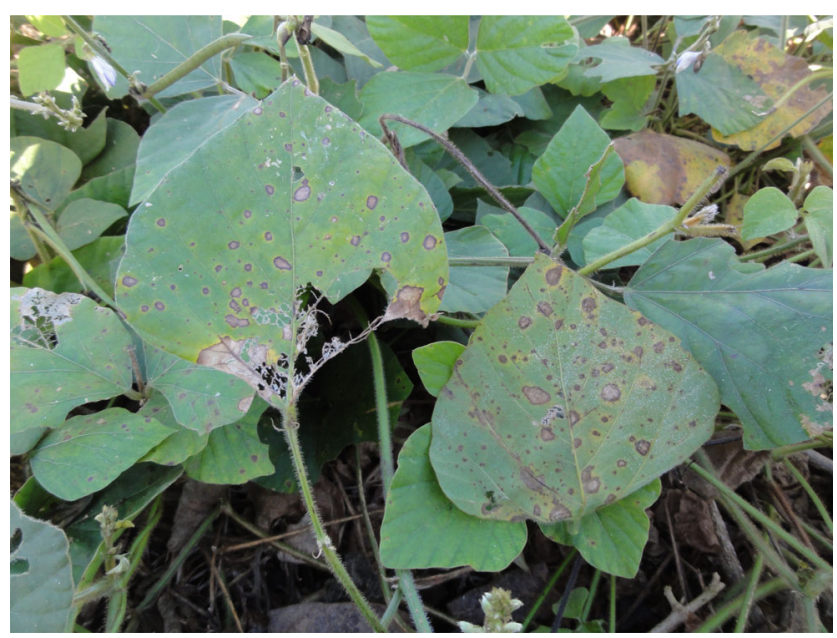

Fig. 1 Corynespora cassiicola leaf spots on Pueraria phaseoloides

plugs obtained from the margin of actively growing COAD 1834 colonies, followed by a $48 \mathrm{~h}$ dew period at $25^{\circ} \mathrm{C}$. Two healthy TK were sprayed with sterile water and had PDA plugs deposited on leaves to serve as control and treated as above. After the dew period plants were left on a greenhouse bench and observed daily for the appearance of symptoms. Typical disease symptoms appeared 4-7 days after inoculation
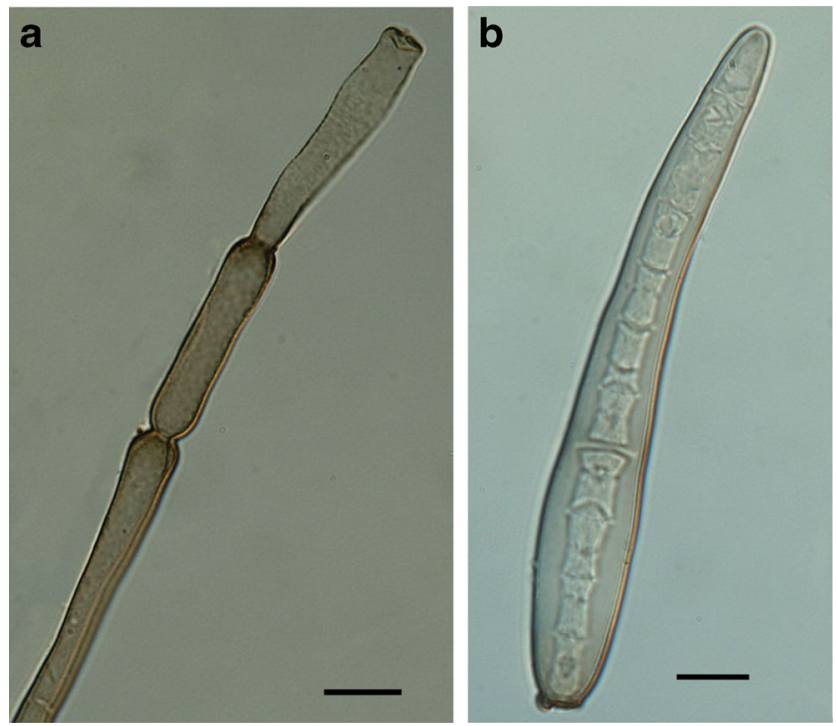

Fig. 2 Corynespora cassiicola on Pueraria phaseoloides. a: Conidiophore showing percurrent proliferation of conidiogenous cell. $\mathbf{b}$ : Conidium. Bars: $30 \mu \mathrm{m}$ regardless of the kind of inoculum that was utilized. Later, C. cassiicola conidiophores and conidia emerged from infected tissues and the fungus was isolated again in pure culture from these colonies.

Corynespora cassiicola is a pantropical plant pathogen with a wide host range of more than a hundred hosts, including numerous legume species (Farr and Rossman 2015) and has many host-specific strains (Onesirosan et al. 1974; Pereira et al. 2003; Dixon et al. 2009; Macedo et al. 2013). This taxon is in need of a monographic work and may represent a complex of species instead of only one entity. Nevertheless, it is out of the scope of this note to resolve it. This is the first report of $C$. cassiicola causing leaf spots on $P$. phaseoloides worldwide.

\section{References}

Deminicis BB (2009) Recursos genéticos de leguminosas tropicais em pastagens e utilização na alimentação de Ruminantes. In: Damasceno AA (ed) Leguminosas forrageiras tropicais: características importantes, recursos genéticos, e causas dos insucessos de pastagens consorciadas. Viçosa, Brazil, pp 61-122

Dixon LJ, Schlub RL, Pernezny K, Datnoff LE (2009) Host specialization and phylogenetic diversity of Corynespora cassiicola. Phytopathology 99:1015-1027

Ellis MB, Holliday P (1971) Corynespora cassiicola. CMI Descriptions Pathogenic Fungi Bacteria 303:1-2

Farr DF, Rossman AY (2015) Systematic Mycology and Microbiology Laboratory, ARS, USDA. http://nt.ars-grin.gov/fungaldatabases/. Accessed 18th August 2015

Macedo DMM, Pereira OL, Wheeler GS, Barreto RW (2013) Corynespora cassiicola f. sp. schinii, a potential biocontrol agent for the weed Schinus terebinthifolius in the United States. Plant Dis 97:496-500

Mendes MAS, Urben AF (2015) Fungos relatados em plantas no Brasil, Laboratório de Quarentena Vegetal. Brasília, DF: Embrapa Recursos Genéticos e Biotecnologia. http://pragawall. cenargen.embrapa.br/aiqweb/michtml/fgbanco01.asp. Accessed 12 November 2015

Onesirosan PT, Arny DC, Durbin RD (1974) Host specificity of Nigerian and North American isolates of Corynespora cassiicola. Phytopathology 64:1364-1367

Pereira JM, Barreto RW, Ellison CA, Maffia LA (2003) Corynespora cassiicola $\mathrm{f}$. sp. lantanae: a potential biocontrol agent from Brazil for Lantana camara. Biol Control 26:21-31

White TJ, Bruns T, Lee S, Taylor JW (1990) Amplification and direct sequencing of fungal ribosomal RNA genes for phylogenetics. In: Innis MA, DH Gelfand, JJ Sninsky, TJ White (eds) PCR protocols: a guide to methods and applications. Academic Press Inc., New York, pp 315-322 